\title{
Responses in apparent total tract digestibility, rate of passage, growth performance and physicochemical properties of the digesta of Windsnyer pigs fed on increasing levels of potato hash silage
}

\author{
Cyprial N. Ncobela ${ }^{1, *}$, Arnold T. Kanengoni ${ }^{2}$, Michael Chimonyo ${ }^{3}$, and Vuyisa A. Hlatini ${ }^{3}$
}

\author{
* Corresponding Author: Cyprial N. Ncobela \\ Tel: +27-12-672-9056, Fax: +27-12-342-8024, \\ E-mail: NcobelaC@arc.agric.za \\ ${ }^{1}$ Agricultural Research Council-Animal \\ Production (Nutrition Building), Private Bag \\ X2, Irene 0062, South Africa \\ ${ }^{2}$ Veterinary Services and Research \\ Department, Joburg Zoo, Private Bag X13, \\ Parkview 2122, South Africa \\ ${ }^{3}$ Animal and Poultry Science, School of \\ Agricultural, Earth and Environmental \\ Sciences, University of KwaZulu-Natal, P \\ bag X01 Scottsville 3209, Pietermaritzburg, \\ South Africa \\ ORCID \\ Cyprial N. Ncobela \\ https://orcid.org/0000-0002-9190-3250 \\ Arnold T. Kanengoni \\ https://orcid.org/0000-0001-5996-0733 \\ Michael Chimonyo \\ https://orcid.org/0000-0002-3206-3191 \\ Vuyisa A. Hlatini \\ https://orcid.org/0000-0002-4246-1011
}

Submitted Aug 11, 2021; Revised Sept 3, 2021; Accepted Sept 18, 2021
Objective: The study was conducted to determine the apparent total tract digestibility (ATTD), the rate of digesta passage, growth performance and physicochemical properties of the digesta of Windsnyer pigs fed on increasing levels of potato hash silage.

Methods: Diets were formulated to contain 0, 80, 160, 240, 320, and 400 g potato hash silage/kg of diet. Pigs were randomly assigned to six diets according to a completely randomized design. Six pigs were allocated to each dietary treatment. All diets were blended with chromic oxide $\left(\mathrm{Cr}_{2} \mathrm{O}_{3}\right)$ to calculate ATTD and rate of passage. Pigs were fed diets containing different levels of potato hash silage for $5 \mathrm{~d}$, following $7 \mathrm{~d}$ of adaptation. Thereafter, pigs were subjected to a 35-day growth performance experiment. Thirty-six pigs were slaughtered and eviscerated to determine digesta characteristics and gut compartment weights.

Results: There was a positive correlation $(\mathrm{p}<0.05)$ between mean retention time and each of digestibility of dry matter, organic matter, and crude protein. There was a quadratic increase $(\mathrm{p}<0.05)$ in digestibility of organic matter, crude protein, fibre and feed intake as dietary levels of potato hash silage increased. Average daily gain and gain to feed ratio decreased linearly $(\mathrm{p}<0.05)$ in pigs as levels of potato hash silage increased. The swelling capacity (SWC) of the digesta from ileum decreased linearly $(\mathrm{p}<0.05)$ as dietary levels of potato hash silage increased. The SWC of the digesta from the caecum increased linearly $(\mathrm{p}<0.05)$ as dietary levels of potato hash silage increased. The water holding capacity (WHC) of the stomach digesta decreased linearly $(\mathrm{p}<0.05)$ as dietary levels of potato hash silage increased. The WHC of the digesta from the ileum and caecum displayed negative quadratic responses $(\mathrm{p}<0.05)$ as dietary levels of potato hash silage increased. The WHC of digesta from the proximal colon showed a linear decline $(\mathrm{p}<0.05)$ as dietary levels of potato hash silage increased. The WHC of digesta from the distal colon increased linearly $(\mathrm{p}<0.05)$ as dietary levels of potato hash silage increased.

Conclusion: The results indicated that Windsnyer pigs can effectively utilize potato hash silage in diets until the $240 \mathrm{~g} / \mathrm{kg}$ inclusion level beyond which total tract digestibility and feed intake are compromised.

Keywords: Feed Intake; Fermentation; Fibre; Gut; Swelling Capacity; Water Holding Capacity

\section{INTRODUCTION}

Sustainability of smallholder pig production in Southern Africa can be strengthened if resource-limited farmers keep hardy genotypes that require less nutrient dense feeds [1]. These include the slow-growing, indigenous pigs found in the region such as the Kolbroek, Mukota, and Windsnyer [2]. Windsnyer pigs have dark-colored skin, stocky compact bodies and long noses, and are hardy. Recent reports state that the population of Windsnyer pigs has dropped significantly raising concerns of the threat of extinction [2]. Windsnyer pigs 
are disfavored owing to a historical bias and negative perceptions associated with the extensive production system under which they have traditionally been raised [3]. In addition, commercial pig production organizations in Southern Africa are in favor of imported breeds and are even promoting them to be used in smallholder production systems [4]. Conserving slow-growing pig genetic resources and improving their productivity is crucial for the smallholder sector economy in developing countries. The Agricultural Research Council (ARC) of South Africa has a program aimed at conserving purebred Windsnyer pigs for breeding, production and research.

The value of Windsnyer pigs lies in, among other things, their adaptability to local environments and tolerance or resistance to endemic diseases and parasites. They have also demonstrated an ability to utilize fibre-rich agricultural byproducts such as maize cobs, better than the fast growing imported genotypes [4]. There is need to investigate how well they can utilize, potato hash, a waste product derived from processing of potatoes (Solanum tuberosum). Potato hash is rich in metabolizable energy (11.2 to $11.4 \mathrm{MJ} / \mathrm{kg}$ dry matter [DM]), starch (700 to $704 \mathrm{~g} / \mathrm{kg} \mathrm{DM}$ ), crude fibre (360 to 370 $\mathrm{g} / \mathrm{kg} \mathrm{DM}$ ) and has low levels of crude protein (CP) (105 to $110 \mathrm{~g} / \mathrm{kg} \mathrm{DM}$ ) [5,6]. It is available in large quantities in certain places and can provide an alternative and sustainable feeding resource for smallholder pig farmers. Potato hash has been overlooked as a feed resource owing to its high moisture content that makes it spoil quickly. A cheap and appropriate preservation strategy to enable the utilisation of the potato hash would be ensiling, but it comes with challenges. The high moisture content present in potato hash does not bode well for ensiling, but good quality silage can still be obtained if the potato hash can be mixed with absorbents to raise the DM content $[5,6]$. The addition of an absorbent however results in a composite product which needs to be investigated with regard to impact on nutrient digestion, rate of passage and physicochemical properties of the digesta to fully understand its value to Windsnyer pigs. The physicochemical properties of a feed include water holding capacity (WHC), viscosity and swelling capacity (SWC), and have a direct effect on digestibility, absorption of nutrients and rate of passage [7]. The objective of the study was, therefore, to determine responses in apparent total digestibility, rate of passage, growth performance and physicochemical properties of the digesta of growing Windsnyer pigs fed on increasing levels of potato hash silage. It was hypothesized that there is an increase in apparent total tract digestibility (ATTD) of nutrients, rate of passage and digesta characteristics with increasing levels of potato hash silage in the diet.

\section{MATERIALS AND METHODS}

\section{Study site}

The study was conducted at the ARC, Animal Production Institute, Irene, South Africa. The institute lies at $25^{\circ} 34^{\prime} 0^{\prime \prime} \mathrm{S}$ and $28^{\circ} 22^{\prime} 0^{\prime \prime} \mathrm{E}$ and is approximately $1,526 \mathrm{~m}$ above sea level. The average annual temperature is $18.7^{\circ} \mathrm{C}$.

\section{Animals, experimental design and diets}

The use and care of the experimental animals were approved by the ARC, Animal Production Institute Ethics committee, South Africa (Reference number: APIEC16/015). Thirty-six clinically healthy male growing Windsnyer pigs with an average initial body weight of $22 \pm 4.43 \mathrm{~kg}$ (mean \pm standard deviation), aged between three and four months were selected from the indigenous pig herd of the ARC and used in the current study. The Windsnyer pigs were moved from the indigenous pig herd where they were housed in groups, to a trial facility where they were individually penned in $1.0 \times 0.9 \mathrm{~m}^{2}$ pens with slatted concrete floors. Each pen was equipped with a single-space feeder and a low-pressure nipple drinker. The temperature and relative humidity in the experimental house were maintained at $24.5^{\circ} \mathrm{C}\left( \pm 1.9^{\circ} \mathrm{C}\right)$ and $62.7 \%( \pm 15.07 \%)$, respectively. The temperature and relative humidity were recorded every $30 \mathrm{~min}$ with log tags. The 36 pigs were randomly assigned to experimental diets containing $0,80,160,240,320$, and 400 g potato hash silage/ $\mathrm{kg}$ of diet. The total mixed diets with increasing levels of potato hash silage were formulated to meet or exceed other nutritional requirements of slow-growing pigs [8], using the Winfeed software program. The experimental diet compositions are shown in Table 1 . The six dietary treatments were replicated 6 times with each Windsnyer pig used as an experimental unit. The pigs were adapted to the feed with $\mathrm{Cr}_{2} \mathrm{O}_{3}$ for $7 \mathrm{~d}$ before data collection for passage rate and ATTD determinations. After the digestibility study, a 35-d growth performance study was undertaken.

\section{Collection and ensiling of potato hash}

Fresh potato hash was collected from a local food producing company (Simba, Johannesburg, South Africa) and brought to the ARC institute for ensiling. The potato hash was blended with ground maize cobs to increase the DM content to between 250 and $400 \mathrm{~g} / \mathrm{kg}$ from the $152 \mathrm{~g} / \mathrm{kg}$ DM of fresh potato hash as obtained from the potato producing company before ensiling. The potato hash-maize cob mixture was in a ratio of 7:3 respectively. The mixture was then ensiled by compacting in 210-L drums lined with polyethylene plastic bags. After compaction, the plastic bags were knotted and tightened to prevent aerobic conditions. The drums were closed with a rubber lid to prevent damage to the bags by rodents. The drums were stored at temperatures ranging from $22^{\circ} \mathrm{C}$ to $29^{\circ} \mathrm{C}$. The silage drums were opened weekly after mixing of the diets to prevent spoilage. The silage was 
Table 1. Ingredients of experimental diets used for growing Windsnyer pigs ( $\mathrm{g} / \mathrm{kg}$ dry matter)

\begin{tabular}{|c|c|c|c|c|c|c|}
\hline \multirow{2}{*}{ Ingredient } & \multicolumn{6}{|c|}{ Inclusion levels of potato hash silage (g/kg dry matter) } \\
\hline & 0 & 80 & 160 & 240 & 320 & 400 \\
\hline Yellow maize & 693 & 612 & 558 & 487 & 410 & 328 \\
\hline Soybean meal & 160 & 167 & 170 & 186 & 190 & 200 \\
\hline Potato hash silage & 0 & 80 & 160 & 240 & 320 & 400 \\
\hline Wheat bran & 85.5 & 75 & 50 & 25 & 20 & 10 \\
\hline Molasses & 20 & 20 & 20 & 20 & 20 & 20 \\
\hline Feed lime & 20 & 21 & 17.7 & 16.8 & 15.9 & 15 \\
\hline Monocalcium & 3.5 & 4.8 & 5.9 & 7.2 & 8.9 & 9.7 \\
\hline Sunflower oil & 5 & 4.8 & 4.7 & 4.5 & 4 & 4 \\
\hline Salt & 4 & 4 & 4 & 4 & 4 & 4 \\
\hline L-Lysine HCL & 4 & 4.6 & 4.5 & 3.7 & 3.7 & 3.8 \\
\hline Methionine & 0.5 & 1.6 & 1.1 & 1.0 & 1.0 & 1.0 \\
\hline Threonine & 1.0 & 1.5 & 1.2 & 1.0 & 1.0 & 1.1 \\
\hline Vitamin-mineral premix ${ }^{1)}$ & 4 & 4 & 4 & 4 & 4 & 4 \\
\hline
\end{tabular}

1) Provides (per kg of DM of diet): vitamin $A, 4.8 \mathrm{mg}$; vitamin $D_{3}, 0.09$ mg; vitamin $E, 50$ mg; vitamin $K_{3}(43 \%), 1.0$ mg; vitamin $B_{1}, 1.6$ mg; vitamin $B_{2}, 2.6$ mg; niacin (99.5\%), 33.6 mg; vitamin $B_{12}, 0.01$ mg; vitamin $B_{6} 98 \%, 2.0$ mg; choline (chloride 60\%), 121 mg; folic acid (96\% pure), 0.48 mg; biotin, 0.18 mg; calcium pantothenate (98\%), 5.2 mg; zinc balitracin, 90.0 mg; manganese sulphate, 120.0 mg; zinc, 100 mg; copper, 8 mg; potassium iodide (lodine $76.45 \%$ ), 0.4 mg; cobalt sulphate, $0.2 \mathrm{mg}$; ferrous sulphate, $100.0 \mathrm{mg}$ and selenium, $0.32 \mathrm{mg}$ on dolomite carrier.

fed to pigs within 6 months of its making.

\section{Measurements of passage rate and apparent total tract nutrient digestibility}

Before offering the pigs feed containing $\mathrm{Cr}_{2} \mathrm{O}_{3}$ as an inert marker, faecal samples from each pig were collected at 07:30 and were denoted as blank samples. Two grams per kilograms of $\mathrm{Cr}_{2} \mathrm{O}_{3}$ were thoroughly blended with the experimental diets. It was ensured that pigs were not hungry before they were offered the marked feed. Pigs were offered 1 to $1.2 \mathrm{~kg}$ of unmarked feed at 08:00 in the morning. They were, afterwards, supplemented with at most $1 \mathrm{~kg}$ of marked feed at 17:00 depending on each one's ability to finish feed offered in the morning. The feed was offered to ensure it was $80 \%$ to $90 \%$ of ad libitum. The time when the pig put its head into the feeder was recorded and denoted as initial time of feed consumption. The pigs were visually monitored for the first appearance of marker every hour starting from 12 $h$ of consumption of marked meal. Thereafter, the time to which first appearance of the marked faeces was recorded. Subsequently, the urine-free fresh faecal samples were collected in 4-h intervals from pens for $48 \mathrm{~h}$ to determine the chromium concentration. After that, all faeces, in each pen, defecated from 07:30 am to 19:30 pm were collected once a day for $5 \mathrm{~d}$ for the estimation of total faecal weights and apparent total tract nutrient digestibility. The collected faecal samples were refrigerated at $-20^{\circ} \mathrm{C}$ immediately after collection, pending analyses. At the end of the collection period, samples were thawed overnight and dried at $60^{\circ} \mathrm{C}$ for $24 \mathrm{~h}$ before analyses. For the rate of passage determination, faecal samples for each pig at a given collection time were dried separately and were analysed for chromium concentration.
For total tract digestibility determination, the 5-d faeces for each pig were combined and mixed after the drying period and then representative samples were analysed.

\section{Calculation of rate of passage, faecal scoring and digestibility}

The transit time (TT) was measured as the time between consumption of marked meal and first appearance of the marker in the faeces. The mean retention time (MRT, in hours) in the entire gastrointestinal tract (GIT) was calculated by a non-compartmental method. The term non-compartmental is used when there is no attempt made to link the MRT to the anatomical or physiological compartments. It is a suitable method when predicting total tract MRT [9]. This method does not require specific objectives and hypotheses regarding response patterns of marker excretion over time. The MRT of the digestive tract (between ingestion of the marked feed and excretion in faeces) was calculated according to equation described by Faichney [10] for total cumulative feed marker collection:

$$
M R T \text { (in hours) }=\sum_{i=1}^{n} m_{i} t_{i}
$$

Where $t_{i}$ is the time (in hours) between the sampling interval and $m_{i}$ is the concentration of marker excreted in the faeces.

The faecal scoring in each pig for $5 \mathrm{~d}$ was visually scored as: $1=$ watery, $2=$ semi-watery, $3=$ normal, $4=$ semi-dry, 5 $=$ dry.

The ATTD of DM (DMD), organic matter (OMD), CP 
(CPD), neutral detergent fibre (NDFD), and acid detergent fibre (ADFD) was calculated based on chromium concentrations in feed and faeces. The formula used for the calculation of apparent total tract nutrient digestibility was:

$$
\text { ATTD }=100-\left(\frac{\% \text { Nutrient faeces }}{\% \text { Nutrient feed }} \times \frac{\% \text { Indicator feed }}{\% \text { Indicator faeces }}\right)
$$

Where ATTD is the apparent total tract digestibility as a coefficient; nutrient faeces is the percentage of nutrient in the faeces; nutrient feed is the percentage of nutrient in the feed; indicator feed is the percentage of chromium in the feed; indicator faeces is the percentage of chromium in the faeces.

Measurements of feed intake and growth performance The feed intake and growth performance experiment was carried out over 35 days and water and feed were offered $a d$ libitum. Average daily feed intake (ADFI) was calculated as feed consumed minus orts and spillage in each week divided by seven. Plastic trays were placed underneath each feeder in the pen to collect spillages. Feed spillages and orts were subtracted from the total weight of feed given to pigs each week. Feed given, feed spillages and orts were weighed using a digital platform scale (max. $300 \mathrm{~kg}$ ) from SCALERITE SCALES, Centurion, South Africa. Average daily gain (ADG) for each week was calculated as final weight minus the initial weight divided by seven. The pigs were weighed using the Livestock Scales - Micro T7E Pig Scale (Premier Scale Services, Centurion, South Africa). The gain:feed ratio was calculated as ADG divided by ADFI.

Slaughtering of pigs and measurements of digesta $\mathrm{pH}$, digesta compartment and weights

All 36 pigs were transported to an abattoir situated about 1.5 $\mathrm{km}$ from the trial facility at $0830 \mathrm{~h}$. The pigs were treated according to the routine abattoir protocols, which included ante-mortem inspection. The pigs were stunned using the electrical stunner set at 220 Volts and 1.8 Amps with the current flow of $6 \mathrm{~s}$. They were subsequently exsanguinated within $10 \mathrm{~s}$ of stunning. They were, then, dipped into water heated to $150^{\circ} \mathrm{C}$ for $3 \mathrm{~min}$. Afterwards, they were dehaired and eviscerated. The GIT (from oesophagus to rectum) were separated from the carcass. The GIT was ligated at the beginning and end of each gut compartment by double tying and cutting to avoid to the flow of digest from and to other gut compartments. Five gut compartments namely stomach, ileum, caecum, proximal and distal colon were used. The ileum was determined as the section, which covers about $100 \mathrm{~cm}$ of small intestine before the ileo-caecal ostium [11]. The caecum and colon were considered as part of the gut entering the pelvic cavity and reaching the rectum part of gut that is attached to the anus. The colon compartment was separated into two equal parts namely proximal and distal colon. About $20 \mathrm{~g}$ of digesta sample was collected from each compartment and put into $50 \mathrm{~mL}$ plastic bottles. Immediately thereafter, $\mathrm{pH}$ was assessed using a Crison 5202 glass $\mathrm{pH}$ electrode. The digesta sample was then frozen at $-20^{\circ} \mathrm{C}$ pending analyses of physicochemical properties. The weights of the compartments and digesta were measured using a digital scale (MZP Precise Electronic Balance $50 \mathrm{~kg} / 0.1 \mathrm{~g}$ digital weighing scales). The weights of stomach, small intestine, caecum and colon were determined by dividing the weights of the gut compartment by the slaughter body weight. The weights of the gut compartments and digesta were scaled to account for the differences in body weights.

\section{Chemical and physicochemical analyses of the diets, faeces and digesta}

Samples of all diets, faeces and digesta were collected and analysed in triplicate (Table 2). Procedures from AOAC [12] were used to determine the DM (DM, method 2001.12), ash (method 942.05), crude protein (CP, method 990.03) and ether extract (EE, method 963.15). Neutral detergent fibre (NDF) and acid detergent fibre (ADF) were determined according to ANKOM Technology Method as explained by Van Soest et al [12]. The NDF content was assayed using heat stable a-amylase (Sigma A3306; Sigma Chemical Co., St. Louis, MO, USA). Gross energy of potato hash silage and experimental diets were determined with bomb calorimetry (MS-1000 modular calorimeter; Energy Instrumentation, Centurion, South Africa). Calcium and phosphorus contents were determined by atomic absorption flame spectroscopy, according to method 6.5 .1 of AOAC [13]. The bulk density of the diets and potato hash silage was measured using the water displacement method, as described by Kyriazakis and Emmans [14]. Briefly, $50 \mathrm{~g}$ of feed were weighed and placed into a $250 \mathrm{~mL}$ volumetric flask containing $100 \mathrm{~mL}$ distilled water in a water-bath at $37^{\circ} \mathrm{C}$. After mixing, an additional 50 $\mathrm{mL}$ of water were added and the contents were allowed to equilibrate for $15 \mathrm{~min}$. Additional $50 \mathrm{~mL}$ water were then added. After allowing $15 \mathrm{~min}$ to equilibrate, the flask was filled by adding water. The total amount of water contained in the flask was subtracted from $250 \mathrm{~mL}$. The WHC of diets was measured using the centrifugation method as described by Whittemore et al [15]. Briefly, about 0.5 grams of sample were measured into a known weight of a $50 \mathrm{~mL}$ plastic centrifuge tube and $25 \mathrm{~mL}$ distilled water was added. The tubes were sealed firmly and shaken intermittently for $24 \mathrm{~h}$. They were then centrifuged at $6,000 \times \mathrm{g}$ for $15 \mathrm{~min}$ at $20^{\circ} \mathrm{C}$. The supernatant was discarded and fresh weight of the sample was determined. The samples were then dried at $103^{\circ} \mathrm{C}$ for $20 \mathrm{~h}$. The weights of the fluid retained were calculated from the difference between fresh sample and dried sample. The weight 
Table 2. Chemical and physicochemical properties of potato hash silage and experimental diets $(n=3)^{1)}$

\begin{tabular}{|c|c|c|c|c|c|c|c|}
\hline \multirow{2}{*}{ Items } & \multirow{2}{*}{$\begin{array}{l}\text { Potato hash } \\
\text { silage }\end{array}$} & \multicolumn{6}{|c|}{ Potato hash silage inclusion levels (g/kg DM) } \\
\hline & & 0 & 80 & 160 & 240 & 320 & 400 \\
\hline Dry matter (g/kg DM) & 337 & 886 & 845 & 801 & 744 & 730 & 662 \\
\hline Gross energy (MJ/kg DM) & 17.4 & 18.4 & 18.7 & 18.9 & 18.9 & 18.8 & 18.4 \\
\hline Crude protein (g/kg DM) & 132 & 162 & 156 & 154 & 151 & 148 & 141 \\
\hline Ether extract (g/kg DM) & 12.0 & 74.2 & 72.0 & 64.0 & 56.0 & 49.7 & 43.0 \\
\hline Ash (g/kg DM) & 39.4 & 47.8 & 55.7 & 60.3 & 65.9 & 70.9 & 74.2 \\
\hline Calcium (g/kg DM) & - & 6.86 & 7.03 & 7.18 & 7.49 & 7.92 & 8.53 \\
\hline Phosphorous (g/kg DM) & - & 3.64 & 3.77 & 3.82 & 3.92 & 4.43 & 5.12 \\
\hline Neutral detergent fibre (g/kg DM) & 633 & 343 & 344 & 373 & 386 & 396 & 407 \\
\hline Acid detergent fibre (g/kg DM) & 335 & 80.5 & 85.1 & 94.5 & 98.9 & 103 & 108 \\
\hline Acid detergent lignin (g/kg DM) & 324 & 37.3 & 40.8 & 48.7 & 56.2 & 60.3 & 64.5 \\
\hline \multicolumn{8}{|l|}{ Physical properties } \\
\hline Bulk density $(\mathrm{g} / \mathrm{mL})$ & 1.14 & 1.50 & 1.50 & 1.47 & 1.35 & 1.33 & 1.24 \\
\hline Swelling capacity $(\mathrm{mL} / \mathrm{g})$ & 4.85 & 3.13 & 3.20 & 3.33 & 3.55 & 3.56 & 3.70 \\
\hline Water holding capacity $\left(g_{\text {water }} / g_{\text {feed }} D M\right)$ & 8.8 & 3.67 & 3.87 & 4.76 & 5.27 & 5.34 & 5.45 \\
\hline
\end{tabular}

DM, dry matter.

${ }^{1)}$ Number of replications.

of the fluid retained was divided by the weight of the dried sample to determine WHC, which was expressed in $\mathrm{g}$ water/g of dry material. For digesta characteristics, the analysis of digesta WHC was performed on wet materials. A SWC was measured according to Canibe and Bach Knudsen [16]. Samples of the experimental diets and potato hash silage, weighing $2 \mathrm{~g}$ were transferred into $15 \mathrm{~mL}$ measuring plastic tubes. A solution of $9 \mathrm{~g} / \mathrm{L} \mathrm{NaCl}$ containing $0.2 \mathrm{~g} / \mathrm{L} \mathrm{NaN}_{3}$ was added to a final volume of $10 \mathrm{~mL}$ where samples were incubated at $39^{\circ} \mathrm{C}$ in a water shaking bath overnight. After $16 \mathrm{~h}$, the shaker was stopped and samples were left in the water for 1 hour before being taken out to measure the volume occupied by the experimental diets and potato hash silage. The SWC of the digesta was analyzed on freeze-dried materials. For passage rate and digestibility, the concentration of chromium in the representative diets and faeces was determined using inductively coupled plasma atomic emission spectroscopy (Optima 5300 DV Spectrometer; Perkin Elmer, Shelton, CT, USA).

\section{Statistical analyses}

Analysis of the data was performed using the Statistical Analysis System software (SAS, Version 9.1) Pearson's correlation coefficients were estimated to determine the relationship between the rate of digesta passage and nutrient digestibility. A PROC MEANS of SAS [17] procedure was used to determine mean \pm standard error for potato hash silage inclusion level against nutrient utilisation, rate of passage, growth performance and physicochemical properties of the digesta. An orthogonal polynomial contrast of SAS [17] was used to determine linear, quadratic and cubic trends between inclusion levels of ensiled potato hash against nutrient utilisation, rate of passage and physicochemical properties of the digesta.

\section{RESULTS}

Apparent total tract digestibility of nutrients and rate of digesta passage

All the pigs were healthy and consumed readily the feed with the marker. The rate of marker recovery was not significantly different across all inclusion levels and ranged from 90\% to $95 \%$. As inclusion levels of potato hash silage increased, the durations between defaecation episodes was shorter. The TT was positively correlated with $\mathrm{DMD}, \mathrm{OMD}, \mathrm{CPD}$, and NDFD $(\mathrm{p}<0.05)$ as shown in Table 3 . There was also a positive correlation $(\mathrm{p}<0.05)$ between MRT and each of DMD, OMD, and CPD. Effects of dietary levels of potato hash silage on apparent total tract nutrient digestibility and rate of digesta passage in growing Windsnyer pigs are shown in Table 4 . The $\mathrm{DMD}, \mathrm{OMD}, \mathrm{CPD}$, and NDFD displayed a quadratic increase $(\mathrm{p}<0.05)$ as inclusion level of potato hash silage increased as shown in Table 5. The maximum digestibility coefficients for DM (0.92), OM (0.93), CP (0.84), and NDF (0.75) were at the $240 \mathrm{~g}$ potato hash $/ \mathrm{kg}$ diet inclusion level. The inclusion level of potato hash had no effect on faecal scores. There was a linear decrease $(\mathrm{p}<0.05)$ in TT with increase in inclusion levels of potato hash silage. The MRT had a negative quadratic response $(\mathrm{p}<0.05)$ as inclusion levels of potato hash silage increased with the highest retention time of $23.8 \mathrm{~h}$ at the $80 \mathrm{~g}$ potato hash $/ \mathrm{kg}$ diet inclusion level. There was a linear increase $(\mathrm{p}<0.05)$ in fresh and dry faecal weight as inclusion levels of potato hash silage increased.

\section{Feed intake and growth performance}

The growth performance parameters of the pigs fed on different inclusion levels of potato hash silage are shown in Table 5 . The daily feed intake had a quadratic increase $(\mathrm{p}<0.05)$ to 
Table 3. Pearson's correlation coefficients between nutrient digestibility and rate of digesta passage

\begin{tabular}{lccccccc}
\hline Component & TT & MRT & DMD & OMD & CPD & ADFD & NDFD \\
\hline TT & - & $0.03^{\text {ns }}$ & $0.49^{\star \star}$ & $0.51^{\star \star}$ & $0.56^{\star \star}$ & $0.19^{\text {ns }}$ & $0.52^{\star}$ \\
MRT & - & - & $0.39^{\star}$ & $0.35^{\star}$ & $0.34^{\star}$ & $0.17^{\text {ns }}$ & $0.31^{\text {ns }}$ \\
DMD & - & - & - & $0.53^{\star \star}$ & $0.52^{\star \star}$ & $0.04^{\text {ns }}$ & $0.35^{\star}$ \\
OMD & - & - & - & - & $0.79^{\star \star}$ & $0.22^{\text {ns }}$ & $0.74^{\star \star \star}$ \\
CPD & - & - & - & - & - & $0.01^{\text {ns }}$ & $0.73^{\star \star \star}$ \\
ADFD & - & - & - & - & - & - & - \\
NDFD & - & - & - & - & - & - \\
\hline
\end{tabular}

$\mathrm{TT}$, transit time; MRT, mean retention time; DMD, dry matter digestibility; OMD, organic matter digestibility; CPD, crude protein digestibility; ADFD, acid detergent fibre digestibility; NDFD, neutral detergent fibre digestibility.

$\star \star \star p<0.001 ; * \star p<0.01 ; * p<0.05 ;$ ns, not significant.

Table 4. Effects of dietary levels of potato hash silage on nutrient digestibility and rate of digesta passage in growing Windsnyer pigs

\begin{tabular}{|c|c|c|c|c|c|c|c|c|c|}
\hline \multirow{2}{*}{ Variables } & \multicolumn{6}{|c|}{ Means of potato hash silage inclusion level (g/kg DM) } & \multirow{2}{*}{ SEM } & \multicolumn{2}{|c|}{$\begin{array}{l}\text { Orthogonal polynomial contras } \\
\text { (p-value })^{1)}\end{array}$} \\
\hline & 0 & 80 & 160 & 240 & 320 & 400 & & Linear & Quadratic \\
\hline DMD & 0.87 & 0.88 & 0.91 & 0.92 & 0.87 & 0.85 & 0.02 & 0.195 & 0.001 \\
\hline OMD & 0.91 & 0.92 & 0.92 & 0.93 & 0.90 & 0.89 & 0.03 & 0.825 & 0.002 \\
\hline CPD & 0.80 & 0.82 & 0.84 & 0.84 & 0.80 & 0.79 & 0.04 & 0.890 & 0.0001 \\
\hline NDFD & 0.68 & 0.70 & 0.72 & 0.75 & 0.64 & 0.63 & 0.05 & 0.487 & 0.04 \\
\hline ADFD & 0.45 & 0.43 & 0.42 & 0.43 & 0.42 & 0.43 & 0.04 & 0.897 & 0.693 \\
\hline Transit time (h) & 17.6 & 17.4 & 17.2 & 17.1 & 16.6 & 15.6 & 0.45 & 0.003 & 0.246 \\
\hline Mean retention time (h) & 23.7 & 23.8 & 21.5 & 20.0 & 18.3 & 18.1 & 2.91 & 0.04 & 0.007 \\
\hline Faecal scores ${ }^{2)}$ & 2.92 & 2.52 & 2.87 & 3.05 & 4.49 & 3.08 & 0.69 & 0.546 & 0.143 \\
\hline Fresh faecal weight (kg) & 4.71 & 5.14 & 5.67 & 6.23 & 7.98 & 8.55 & 0.59 & 0.0003 & 0.275 \\
\hline Dry faecal weight (kg) & 1.35 & 1.58 & 1.89 & 2.23 & 2.67 & 3.12 & 0.37 & 0.004 & 0.367 \\
\hline
\end{tabular}

DM, dry matter; SEM, standard error of the mean; DMD, dry matter digestibility; OMD, organic matter digestibility; CPD, crude protein digestibility; NDFD, neutral detergent fibre digestibility; ADFD, acid detergent fibre digestibility.

1) Cubic response was not observed.

2) Faecal scores 1 = watery, 2 = semi-watery, $3=$ normal, $4=$ semi-dry, $5=$ dry.

dietary inclusion level of potato hash silage with the maximum intake $(1.92 \mathrm{~kg})$ at the $240 \mathrm{~g}$ potato hash $/ \mathrm{kg}$ diet inclusion level. There was linear decrease $(\mathrm{p}<0.05)$ in each of the ADG and gain to feed ratio with increasing levels of potato hash silage.

Weights of compartments of the gastrointestinal tract and digesta characteristics

The effects of dietary levels of potato hash silage on scaled digesta and gut compartment weights are shown in Table 6. There were linear increases $(\mathrm{p}<0.05)$ in scaled compartment weights of the stomach and colon with increase in inclusion levels of potato hash silage. There was a linear increase $(p<0.05)$ in scaled digesta weight from the colon with increasing levels of potato hash silage. The effects of dietary levels of potato hash silage on digesta $\mathrm{pH}$ in the GIT compartments are shown in Table 7. There was a linear increase $(\mathrm{p}<0.05)$ in ileum digesta $\mathrm{pH}$ as inclusion levels of potato hash silage increased. The $\mathrm{pH}$ of the digesta from the caecum and proximal colon were not affected by the inclusion levels of potato hash silage ( $p>$ $0.05)$. The $\mathrm{pH}$ of the digesta from the distal colon decreased linearly $(p<0.05)$ as inclusion levels of potato hash silage in-

Table 5. Effects of dietary levels of potato hash silage on feed intake and growth performance in growing Windsnyer pigs

\begin{tabular}{|c|c|c|c|c|c|c|c|c|c|}
\hline \multirow{2}{*}{ Variables } & \multicolumn{6}{|c|}{ Means of potato hash silage inclusion level (g/kg DM) } & \multirow{2}{*}{ SEM } & \multicolumn{2}{|c|}{$\begin{array}{l}\text { Orthogonal polynomial contrast } \\
\qquad(p-v a l u e)^{1)}\end{array}$} \\
\hline & 0 & 80 & 160 & 240 & 320 & 400 & & Linear & Quadratic \\
\hline Daily feed intake (kg) & 1.52 & 1.65 & 1.74 & 1.92 & 1.68 & 1.56 & 0.07 & 0.124 & 0.005 \\
\hline Average daily gain $(\mathrm{kg})$ & 0.48 & 0.46 & 0.45 & 0.42 & 0.35 & 0.31 & 0.04 & 0.0001 & 0.164 \\
\hline Gain to feed ratio & 0.31 & 0.28 & 0.25 & 0.23 & 0.21 & 0.19 & 0.03 & 0.0001 & 0.214 \\
\hline
\end{tabular}

DM, dry matter; SEM, standard error of the mean.

${ }^{1)}$ Cubic response was not observed. 
Table 6. Effects of dietary levels of potato hash silage on scaled digesta and compartment weights (g/kg BW/d)

\begin{tabular}{|c|c|c|c|c|c|c|c|c|c|}
\hline \multirow[t]{2}{*}{ Variable } & \multicolumn{6}{|c|}{ Means of potato hash silage inclusion level (g/kg DM) } & \multirow[t]{2}{*}{ SEM } & \multicolumn{2}{|c|}{$\begin{array}{l}\text { Polynomial orthogonal contrast } \\
\qquad(p-\text { value })^{1)}\end{array}$} \\
\hline & 0 & 80 & 160 & 240 & 320 & 400 & & Linear & Quadratic \\
\hline Scaled stomach & 9.4 & 11.6 & 10.3 & 11.6 & 11.6 & 14.7 & 0.75 & 0.007 & 0.466 \\
\hline Scaled small intestines & 17.0 & 21.5 & 20.7 & 16.8 & 19.9 & 22.2 & 1.85 & 0.182 & 0.212 \\
\hline Scaled caecum & 1.6 & 3.01 & 1.81 & 2.91 & 2.02 & 3.22 & 0.47 & 0.909 & 0.114 \\
\hline Scaled stomach & 25.3 & 17.5 & 18.5 & 20.0 & 32.3 & 22.1 & 4.37 & 0.246 & 0.551 \\
\hline Scaled small intestines & 8.74 & 7.18 & 9.12 & 8.76 & 12.2 & 9.02 & 1.89 & 0.413 & 0.138 \\
\hline Scaled caecum & 14.9 & 7.59 & 11.9 & 10.3 & 16.9 & 9.4 & 2.39 & 0.547 & 0.245 \\
\hline Scaled colon & 11.4 & 12.9 & 13.2 & 17.0 & 16.9 & 27.6 & 2.72 & 0.0002 & 0.267 \\
\hline
\end{tabular}

BW, body weight; DM, dry matter; SEM, standard error of the mean.

${ }^{1)}$ Cubic response was not observed.

Table 7. Effects of dietary levels of potato hash silage on digesta $\mathrm{pH}$ in the ileum, caecum, proximal colon and distal colon

\begin{tabular}{|c|c|c|c|c|c|c|c|c|c|}
\hline \multirow{2}{*}{ Variable } & \multicolumn{6}{|c|}{ Means of potato hash silage inclusion level ( $\mathrm{g} / \mathrm{kg} \mathrm{DM})$} & \multirow{2}{*}{ SEM } & \multicolumn{2}{|c|}{$\begin{array}{l}\text { Polynomial orthogonal contrast } \\
\qquad(p-\text {-value })^{1)}\end{array}$} \\
\hline & 0 & 80 & 160 & 240 & 320 & 400 & & Linear & Quadratic \\
\hline Stomach digesta & 3.5 & 3.5 & 3.4 & 4.2 & 3.5 & 3.4 & 0.23 & 0.246 & 0.09 \\
\hline Ileum digesta & 5.9 & 6.2 & 6.4 & 6.5 & 6.5 & 6.6 & 0.13 & 0.0001 & 0.147 \\
\hline Caecum digesta & 6.1 & 6.1 & 6.3 & 6.4 & 6.1 & 6.3 & 0.11 & 0.526 & 0.361 \\
\hline Proximal colon digesta & 6.4 & 6.5 & 6.6 & 6.3 & 6.2 & 6.6 & 0.15 & 0.215 & 0.114 \\
\hline Distal colon digesta & 6.8 & 6.7 & 6.6 & 6.4 & 6.4 & 6.3 & 0.11 & 0.004 & 0.264 \\
\hline
\end{tabular}

DM, dry matter; SEM, standard error of the mean.

1) Cubic response was not observed.

creased. The effects of inclusion levels of potato hash silage on SWC and WHC of the digesta on Windsnyer pigs are shown in Table 8. The SWC of the digesta in the stomach increased quadratically $(\mathrm{p}<0.05)$ as inclusion levels of potato hash silage increased with the highest SWC value $(3.45 \mathrm{~mL} / \mathrm{g}$ $\mathrm{DM})$ at the $240 \mathrm{~g}$ potato hash silage inclusion level. The SWC of the digesta from ileum decreased linearly $(\mathrm{p}<0.05)$ when pigs were fed increasing levels of potato hash silage. There was a linear increase $(\mathrm{p}<0.05)$ in SWC of the digesta from the caecum with increase in inclusion levels of potato hash silage. The inclusion levels of potato hash silage did not affect the SWC of the digesta from the proximal and distal colon

Table 8. Swelling capacity and water holding capacity of the digesta from gut compartments of Windsnyer pigs fed potato hash silage

\begin{tabular}{|c|c|c|c|c|c|c|c|c|c|}
\hline \multirow[t]{2}{*}{ Variable } & \multicolumn{6}{|c|}{ Means of potato hash silage inclusion level ( $\mathrm{g} / \mathrm{kg} \mathrm{DM}$ ) } & \multirow[t]{2}{*}{ SEM } & \multicolumn{2}{|c|}{$\begin{array}{l}\text { Orthogonal polynomial contrast } \\
(p-\text {-value })^{1)}\end{array}$} \\
\hline & 0 & 80 & 160 & 240 & 320 & 400 & & Linear & Quadratic \\
\hline \multicolumn{10}{|c|}{ Swelling capacity (mL/g DM) } \\
\hline Stomach digesta & 3.16 & 3.24 & 3.45 & 3.45 & 3.33 & 3.59 & 0.036 & 0.365 & 0.031 \\
\hline Ileum digesta & 3.28 & 2.78 & 2.68 & 2.58 & 2.60 & 2.45 & 0.074 & 0.0002 & 0.092 \\
\hline Caecum digesta & 2.33 & 2.52 & 2.67 & 2.75 & 2.28 & 2.76 & 0.084 & 0.024 & 0.116 \\
\hline Proximal colon digesta & 3.13 & 2.85 & 2.95 & 2.85 & 3.12 & 2.98 & 0.109 & 0.145 & 0.694 \\
\hline Distal colon digesta & 2.45 & 2.38 & 2.47 & 2.45 & 2.42 & 2.40 & 1.605 & 0.324 & 0.106 \\
\hline \multicolumn{10}{|c|}{ Water holding capacity (g water/g DM) } \\
\hline Stomach digesta & 2.68 & 2.59 & 3.47 & 2.46 & 2.46 & 2.39 & 0.361 & 0.0004 & 0.098 \\
\hline Ileum digesta & 4.02 & 3.77 & 3.62 & 3.10 & 3.33 & 3.62 & 0.121 & 0.294 & 0.0001 \\
\hline Caecum digesta & 3.52 & 3.42 & 3.33 & 2.88 & 3.22 & 3.55 & 0.103 & 0.111 & 0.005 \\
\hline Proximal colon digesta & 2.87 & 2.78 & 2.81 & 2.53 & 2.42 & 2.40 & 0.104 & 0.0001 & 0.542 \\
\hline Distal colon digesta & 2.28 & 2.57 & 2.63 & 2.47 & 3.03 & 3.15 & 0.082 & 0.0002 & 0.347 \\
\hline
\end{tabular}

DM, dry matter; SEM, standard error of the mean

1) There was no cubic response observed. 
$(p>0.05)$. The WHC of the digesta in the stomach decreased linearly $(p<0.05)$ as the dietary inclusion of potato hash silage increased. The WHC of the digesta from ileum and also from the caecum decreased quadratically $(\mathrm{p}<0.05)$ as inclusion levels of potato hash silage increased, with the minimum WHC values ( $3.10 \mathrm{~g}$ water/g DM in the ileum; $2.88 \mathrm{~g}$ water/g $\mathrm{DM}$ in the caecum) at the $240 \mathrm{~g}$ potato hash silage inclusion level. The WHC of the digesta from the proximal colon decreased linearly $(p<0.05)$, while there was a linear increase $(p<0.05)$ in WHC of the digesta from the distal colon with increasing levels of potato hash silage.

\section{DISCUSSION}

The uutilization of nutrients by pigs has been reported to be influenced by two simultaneous and dynamic processes namely digestion and digesta TT in the gut [18]. The increased use of non-conventional feedstuffs such as potato hash silage has highlighted the need to better understand the relationship between rate of passage and nutrient digestibility in pigs. When studying indigenous breeds of pigs, it becomes further complicated because it is still unclear how slow-growing pigs are able to utilize fibrous feeds better than the improved breeds [4]. If the mechanism enabling slowgrowing pigs to utilize fibrous feeds involves rate of passage, then such knowledge may contribute to the characterization of the breeds and assist in their conservation efforts. This study assessed the relationship between increasing levels of potato hash silage with ATTD, digesta rate of passage and physicochemical properties of the digesta in growing Windsnyer pigs. There was a significant correlation between MRT and DMD, OMD and CPD. Kim et al [19] similarly reported a positive correlation coefficient between MRT and DMD and suggested that MRT could be used as a potential independent variable in digestibility studies.

The rate of digesta passage is affected by physical and chemical characteristics of the feed, feed processing and feeding level [20]. Potato hash silage is a processed composite product of diverse ingredients with variable non-starch polysaccharide (NSP) and resistant starch components that are likely to interact and affect rate of passage and digestibility in ways difficult to predict. Analysis of diets showed that potato hash had a high WHC which it imputed to the diets as observed by the linear increase in WHC as inclusion level of potato hash increased. There was however a linear decrease in WHC of digesta (as inclusion level of potato hash silage increased) in the stomach and proximal colon and a quadratic response in the ileum and caecum. It would have been expected that as the inclusion level of potato hash silage increased, the WHC of the digesta would increase in the various gut compartments. This is because WHC is related to the amount, composition and structure features of dietary fibre [21]. It is not clear to what extent ensiling and the use of absorbents, viscosity, particle size, structure of fibre had direct or indirect influences on the WHC of the digesta. Anguita et al [21] reported that WHC of the digesta increased from the stomach to ileum and decreased as digesta passed through the hindgut. Similar patterns were observed in this study for all the other diets except for the 320 and $400 \mathrm{~g}$ potato hash silage inclusion level where the WHC of digesta increased in the distal colon. This increment in WHC as levels of potato hash silage increased may be explained by increasing levels of NSPs.

In addition to the WHC, the SWC of the diets and digesta were also investigated. Similarly to WHC, potato hash had a high SWC which it imputed to the diets as observed by the linear increase in SWC as inclusion level of potato hash increased. Swelling forms the first phase of solubilization of NSPs [11]. The SWC of ensiled potato hash is also directly associated with the proportion of resistant starch. However, in the present study resistant starch was not analyzed. A quadratic response to increase in the inclusion level of potato hash silage of the SWC of the digesta in the stomach of pigs is difficult to explain. The linear decrease in SWC of ileum digesta could be related to the $\mathrm{pH}$ in the ileum. The linear increase in $\mathrm{pH}$ in the ileum agrees with Högberg and Lindberg [22] who reported that pigs offered a fibre rich diet had higher $\mathrm{pH}$ values than pigs offered a control diet in the ileum. The linear decrease in $\mathrm{pH}$ in the distal colon could be due to increased production of volatile fatty acids, leading to a lower $\mathrm{pH}$ in the large intestine [23].

Hydrophilic polysaccharides absorb water and hold it in the lumen of the gut giving rise to faster passage rate of the digesta [13]. Potato hash silage has high content of hydrophilic polysaccharides, such as hemicellulose, that can absorb water and hold it in the lumen of the gut. Insoluble NSPs, such as cellulose and xylans found in potato hash, could also hold water as they behave like sponges in the gut, resulting in considerable bulking properties [14]. Potato hash silage, by nature, has high water content, which contributes importantly in mixing of digesta, solubilisation of nutrients, and facilitation of digesta emptying. The negative quadratic response to increases in inclusion level of potato hash silage by MRT was not anticipated and is difficult to explain. It will need further investigation given that its pattern was not consistent with that of TT. High levels of dietary NDF and ADF as in the diet, attributable to maize cobs, are associated with low porosity, low density and may reduce viscosity and MRT. The results of a linear reduction in MRT in this study concur with Wilfart et al [18] who reported that high fibre content caused a major reduction in MRT in the large intestine in pigs. Potato hash has low levels of water-soluble carbohydrates [6], and when blended with maize cobs for ensiling purposes becomes bulky. Bulky feeds such as potato hash silage exert 
a direct physical effect on the gut walls which increases peristatic movements [8]. When levels of water-soluble carbohydrates are low, feed becomes less viscous and rate of passage is shortened. Dietary fibre also has a laxative effect thus, reducing the MRT and consequently inhibiting microbial activity in hindgut. Wilfart et al [18] also observed a high amount of faeces excreted by pigs when fed high levels of dietary fibre as observed in this study. The changes in the physicochemical properties of digesta in each gut compartment implied that monomeric composition and structural arrangements of building blocks of increasing levels of potato hash silage are not uniform and might impose complex physiological effect on the nutrient digestibility [11].

The quadratic increase in ATTD of DM, OM, CP, and $\mathrm{NDF}$ to increases in potato hash inclusion level demonstrates the capacity of Windsnyer pigs to utilise potato hash silage up to a point before digestibility starts to decrease. Kanengoni et al [4] also reported an increase in ATTD of CP and NDF in Windsnyer pigs fed low and high levels maize cob silage. Since ensiling improves the utilisation of fibrous feeds [4], it could therefore be speculated that the proportion of nutrients digested would have been much less if the potato hash was not ensiled. The quadratic increase in feed intake suggests that the pigs consumed more feed to meet their nutrients requirements until their gut capacity was reached, and then feed intake diminished. The linear decrease in ADG and gain to feed ratio may be associated with the negative effects of fibre and glycoalkaloid concentrations in the diets which increased as the level of potato hash silage increased. Potato peels, which contribute the largest portion of potato hash, contain glycoalkaloids that can inhibit nutrient utilisation by pigs [5].

Literature on the effect of fibrous silage on digesta characteristics and gastrointestinal development in pigs is scarce. A linear increase in stomach weight with increase in inclusion levels of potato hash silage could be due to increasing levels of dietary fibre in the diet. Ngoc et al [7] also reported a positive effect of level of dietary fibre on stomach weight. The effects of fibre on gut development depends on specific properties or structural characteristics of fibre source [24]. The fibre may cause intestinal muscle wall hypertrophy owing to increased peristaltic motions and greater weight of digesta; or it may induce epithelial proliferation through the increased production of short chain fatty acids. An increase in colon weights suggests that it is the major site where fermentation of the potato hash silage occurs as also shown by the lower digesta $\mathrm{pH}$ values. Fermentation produces short chain fatty acids which in turn stimulate epithelial cell proliferation. The results of the present study were in agreement with Wate et al [11] who reported a linear increase in colonic intestinal content as maize cob level increased. It is also possible that the contribution of resistant starch to the total starch content of potato hash silage had an influence on the development of the colon compartment.

\section{CONCLUSION}

The positive correlation between rate of passage and nutrient digestibility reiterates that these dynamic processes are interdependent and should be considered when dealing with non-conventional feeds. The positive quadratic response in ATTD of nutrients and feed intake as inclusion level of potato hash increased indicated that Windsnyer pigs are effective and efficient in utilizing fibrous feedstuffs until the $240 \mathrm{~g} / \mathrm{kg}$ inclusion level of potato hash silage, beyond which total tract digestibility and feed intake is compromised. When developing models to predict rate of passage, nutrient digestibility and feed intake, it is vital to consider physicochemical properties of the digesta.

\section{CONFLICT OF INTEREST}

We certify that there is no conflict of interest with any financial organization regarding the material discussed in the manuscript.

\section{FUNDING}

The authors wish to recognise the ARC, Professional development Programme, National Research Foundation, Scarce skills development fund and Gauteng Department of Agriculture and Rural Development for funding the project (Project number: SFH150702122705).

\section{ACKNOWLEDGMENTS}

We wish also to thank late Dr R.S Thomas for his contribution to the project. We also extend our gratitude to $\mathrm{Mr} \mathrm{M}$. Rampedi and Mr K. Nxumalo for helping with collecting data for rate of passage.

\section{REFERENCES}

1. Mashatise E, Hamudikuwanda H, Dzama K, Chimonyo M, Kanengoni A. Effects of corn cob-based diets on the levels of nutritionally related blood metabolites and onset of puberty in Mukota and LandracexMukota gilts. Asian-Australas J Anim Sci 2005;18:1469-74. https://doi.org/10.5713/ajas. 2005.1469

2. Halimani TE, Muchadeyi FC, Chimonyo M, Dzama K. Pig genetic resource conservation: the Southern African perspective. Ecol Econ 2010;69:944-51. https://doi.org/10.1016/j. ecolecon.2010.01.005 
3. Chimonyo M, Dzama K, Bhebhe E, Mapiye C. Pre-weaning performance of the Zimbabwean Mukota and Large Whitex Mukota pigs under low-input production systems. Res Opin Anim Vet Sci 2011;1:352-9.

4. Kanengoni AT, Chimonyo M, Ndimba BK, Dzama K. Feed preference, nutrient digestibility and colon volatile fatty acid production in growing South African Windsnyer-type indigenous pigs and Large White $\times$ Landrace crosses fed diets containing ensiled maize cobs. Livest Sci 2015;171:28-35. https://doi.org/10.1016/j.livsci.2014.10.018

5. Ncobela CN, Kanengoni AT, Hlatini VA, Thomas RS, Chimonyo M. A review of the utility of potato by-products as a feed resource for smallholder pig production. Anim Feed Sci Technol 2017;227:107-117. https://doi.org/10.1016/j.ani feedsci.2017.02.008

6. Nkosi BD, Meeske R. Effects of ensiling totally mixed potato hash ration with or without a heterofermentative bacterial inoculant on silage fermentation, aerobic stability, growth performance and digestibility in lambs. Anim Feed Sci Technol 2010;161:38-48. https://doi.org/10.1016/j.anifeedsci.2010. 07.015

7. Kyriazakis I, Emmans GC. The voluntary feed intake of pigs given feeds based on wheat bran, dried citrus pulp and grass meal, in relation to measurements of feed bulk. Br J Nutr 1995;73:191-207. https://doi.org/10.1079/BJN19950023

8. Carter NA, Dewey CE, Thomas LF, Lukuyu B, Grace B, de Lange C. Nutrient requirements and low-cost balanced diets, based on seasonally available local feedstuffs, for local pigs on smallholder farms in Western Kenya. Trop Anim Health Prod 2016;48:337-47. https://doi.org/10.1007/s11250-0150957-6

9. Lalle's JP, Delval E, Poncet C. Mean retention time of dietary residues within the gastrointestinal tract of the young ruminant: a comparison of non-compartmental (algebraic) and compartmental (modelling) estimation methods. Anim Feed Sci Technol 1991;35:139-59. https://doi.org/10.1016/03778401(91)90106-3

10.Faichney GJ. The use of markers to partition digestion within the gastrointestinal tract of ruminants. In: McDonald IW and Warber ACI, editors. Digestion and metabolism in the ruminant. Armidale, Australia: University of New England Publishing Unit; 1975. pp. 277-91. http://hdl.handle.net/102. 100.100/306725?:index $=1$

11. Wate A, Zindove TJ, Chimonyo M. Effects of feeding incremental levels of maize cob meal on physicochemical properties of bulkiness in digesta in growing pigs. Livest Sci 2014;170: 124-30. https://doi.org/10.1016/j.livsci.2014.10.010

12. Van Soest PV, Robertson JB, Lewis BA. Methods for dietary fiber, neutral detergent fiber, and nonstarch polysaccharides in relation to animal nutrition. J Dairy Sci 1991;74:3583-97. https://doi.org/10.3168/jds.S0022-0302(91)78551-2
13. AOAC. Official methods of analysis, 18th ed. Association of official analytical chemists. Gaithersburg, MD, USA: AOAC; 2005.

14. Kyriazakis I, Emmans GC. The voluntary feed intake of pigs given feeds based on wheat bran, dried citrus pulp and grass meal, in relation to measurements of feed bulk. Br J Nutr 1995;73:191-207. https://doi.org/10.1079/BJN19950023

15. Whittemore EC, Emmans GC, Kyriazakis I. The relationship between live weight and the intake of bulky foods in pigs. Anim Sci 2003;76:89-100. https://doi.org/10.1017/S13577 29800053352

16. Canibe N, Bach Knudsen K. Degradation and physicochemical changes of barley and pea fibre along the gastrointestinal tract of pigs. J Sci Food Agric 2002;82:27-39. https://doi.org/ $10.1002 /$ jsfa. 985

17.SAS. SAS User's guide: statistics, Version9.1. Cary, NC, USA: SAS Institute; 2008.

18. Wilfart A, Montagne L, Simmins H, Noblet J, van Milgen J. Digesta transit in different segments of the gastrointestinal tract of pigs as affected by insoluble fibre supplied by wheat bran. Br J Nutr 2007;98:54-62. https://doi.org/10.1017/S000 7114507682981

19. Kim BG, Lindemann MD, Cromwell GL, Balfagon A, Agudelo $\mathrm{JH}$. The correlation between passage rate of digesta and dry matter digestibility in various stages of swine. Livest Sci 2007; 109:81-4. https://doi.org/10.1016/j.livsci.2007.01.082

20.Le Goff G, Noblet J. Comparative total tract digestibility of dietary energy and nutrients in growing pigs and adult sows. J Anim Sci 2001;79:2418-27. https://doi.org/10.2527/2001. 7992418x

21. Anguita M, Gasa J, Nofrarias M, Martín-Orúe SM, Pérez JF. Effect of coarse ground corn, sugar beet pulp and wheat bran on the voluntary intake and physicochemical characteristics of digesta of growing pigs. Livest Sci 2007;107:182-91. https:// doi.org/10.1016/j.livsci.2006.09.016

22.Högberg A, Lindberg JE. The effect of level and type of cereal non-starch polysaccharides on the performance, nutrient utilization and gut environment of pigs around weaning. Anim Feed Sci Technol 2006;127:200-19. https://doi.org/10. 1016/j.anifeedsci.2005.09.004

23. Bach Knudsen KE, Jensen BB, Andersen JO, Hansen I. Gastrointestinal implications in pigs use of wheat and oat fractions: 2. Microbial activity of the gastrointestinal tract. Br J Nutr 1991;65:233-48. https://doi.org/10.1079/BJN19910083

24.Len NT, Hong TTT, Ogle B, Lindberg JE. Comparison of total tract digestibility, development of visceral organs and digestive tract of Mong cai and Yorkshire $\times$ Landrace piglets fed diets with different fibre sources. J Anim Physiol Anim Nutr 2009;93:181-91. https://doi.org/10.1111/j.1439-0396. 2007.00804.x 